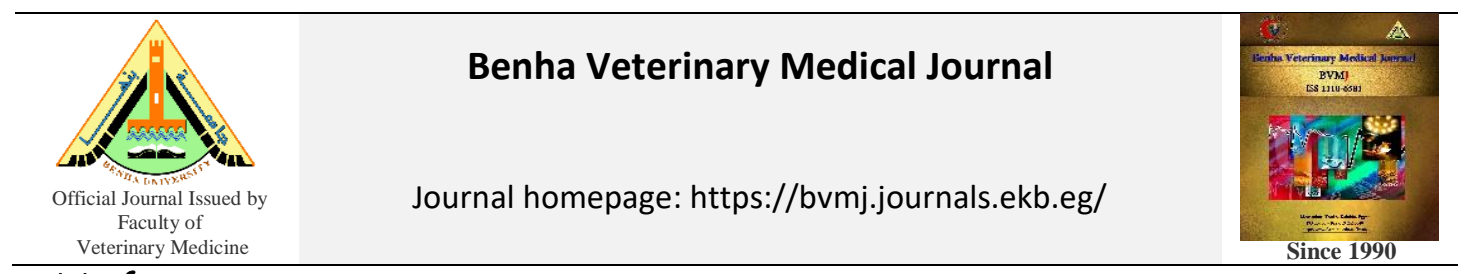

Original Paper

\title{
The effects of live yeast (Saccharomyces cerevisiae) and chitosan on rumen fermentation function and rumen development in male balady goats
}

\author{
Abd- Elkader, A. Y., Azab, M. E., Randa, S. Esmail, Abeer A. Nafeaa, Shousha, S. M.
}

Department of Physiology, Faculty of Veterinary Medicine, Benha University.

\begin{tabular}{l} 
ARTICLE INFO \\
\hline Keywords \\
Balady goat \\
Chitosan \\
Rumen Fermentation \\
Rumen papillae \\
Saccharomyces cerevisiae
\end{tabular}

\begin{abstract}
The present study aimed at comparing the influence of dietary supplementation of live dried yeast (Saccharomyces cerevisiae) and chitosan on rumen fermentation and rumen development in male Balady goats. A total number of 12 one-year old castrated adult male Balady goats (bucks) were allocated into three groups (4 per each). Concentrates were offered at rate of 3\% of body weight. Experimental groups were control group fed on basal diet consists of concentrate mixture without any feed additives, $S$. cerevisiae group fed on basal diet with $S$. cerevisiae at rate of $0.3 \%$ ( $3 \mathrm{Kg} / \mathrm{ton}$ concentrate), and chitosan group fed on basal diet with chitosan at rate of $0.2 \%(2 \mathrm{~kg} /$ ton concentrate). Results showed a significant $(p<0.05)$ increase in total volatile fatty acids concentrations (TVFA), total ruminal protozoal count (TPC), quantitative morphometric analysis of ruminal papillae length, width and number of papillae/surface area $\left(\mathrm{cm}^{2}\right)$ and significant $(p<0.05)$ decrease ruminal ammonia nitrogen concentration in Saccharomyces group when compared with the control group. While, treatment with $S$. cerevisiae or chitosan caused no significant variation $(\mathrm{p}>0.05)$ in ruminal $\mathrm{pH}$ compared to control. Also, There was a non-significant $(p>0.05)$ increase in total volatile fatty acids concentrations (TVFA), total ruminal protozoal count (TPC) and quantitative morphometric analysis of ruminal papillae length, width and significant increase in number of papillae/surface area $\left(\mathrm{cm}^{2}\right)$ in chitosan group when compared with the control group. While, chitosan group showed a significant $(p<0.05)$ increase in ruminal ammonia nitrogen compared with the control. Thus, it is recommended to use S. cerevisiae to improve rumen fermentation, productivity and health care during growth.
\end{abstract}

\section{INTRODUCTION}

Goat meat has gained market mainly due to increased demand for healthy foods because of its low-fat content. Goat plays an essential economic role and makes a significant contribution to both domestic and export markets through the provision of food (meat and milk) and non-food (manure, skin and wool) products (Polizel et al., 2016). Although goat plays a significant role in the national economy of the country to date the benefit obtained from this livestock is hampered by different constrains (Duguma et al., 2011). Ruminants naturally consume high fibrous plant materials and convert it to a marketable commodity, meat, milk and wool. With fiber fermentation in the rumen, energy and microbial protein are obtained for maintenance, growth, lactation and reproduction ( $\mathrm{Lu}$ et al., 2005). Basically, the ruminal microbial fermentation processes can be modified by intervention at three levels: feed, animal, and microbial levels (Nagaraja, 2012). Antibiotics, probiotics and prebiotic have been studied to manipulate the microbial ecosystem and fermentation characteristics in the rumens and intestinal tracts of livestock animals (Seo et al., 2010). The use of antibiotics is banned due to potential risks such as the spread of antibiotic resistance genes or the contamination of milk or meat with antibiotic residues. (Hong et al., 2005). S. cerevisiae as probiotics have been extensively used in ruminants for improving performance and normalizing rumen fermentation (Chevaux and Fabre, 2007). Chitosan, a deacetylated chitin, is widespread prebiotic in nature, the exoskeletons of arthropods such as crabs, shrimps, insects, and other marine creatures in the crustacean family are good sources of chitosan (Li et al., 2009). Chitosan has become a new candidate as a growth-promoter for farm animals. Benefits observed seem to be caused by changes in ruminal fermentation (Goiri et al., 2010). Therefore, the present study was designed to compare between the impacts of feeding of diets containing $S$. cerevisiae and chitosan on rumen fermentation functions and rumen development in male Balady goat.

\section{MATERIAL AND METHODS}

\section{1. Experimental design}

A total number of 12 castrated healthy adult male Balady goats (bucks) aged one-year-old and weighing $24 \pm 1 \mathrm{Kg}$ were obtained from a private farm for Balady goats' production in El-Kalioubia Governorate, Egypt during the period from the end of December 2017 till the end of April 2018 (4 months).

The animals were allocated into three similar groups $(4$ males for each group) with a completely randomized design. Concentrates were offered at a rate of $3 \%$ of live body

\footnotetext{
* Corresponding author: Abd- Elkader, A. Y., Department of Physiology, Faculty of Veterinary Medicine, Benha University.
} 
weight. The feed additives used in this study included are (1) Saccharomyces cerevisiae obtained from Angle Yeast Co., Inc. assay with $3 \times 10^{9} \mathrm{CFU} / \mathrm{gm}$ (brewer's yeast) (2) Chitosan was obtained from marine chemicals co., extracted from crab shells of medium molecular weight, deacetylation degree was $>85 \%$. The animals were reared for 4 months as the $1^{\text {st }}$ month for acclimatization of goats for new environmental conditions, the $2^{\text {nd }}$ month for adaptation to the feed additives and the last two months for collection of samples. All animals were managed at the same environmental and nutritional conditions. The goats were housed in separated pens of the same size (one pen for each group) with special feeders and drinkers. The feed offer 2 times daily and water was supplied ad libitum. The ratio between goats and feeders was 4:1. Goats were fed on concentrate feed mixture ration (its ingredients and its chemical analysis are illustrated in Table (1). Samples of ruminal juice collected at the beginning of the $3^{\text {rd }}$ month of the experiment ( $8^{\text {th }}$ week) then continued every 2 weeks till the end of the experiment ( $16^{\text {th }}$ week) then at the end of the experiment, samples of rumens (Saccus ventralis) were taken for quantitative morphometric analysis of ruminal papillae length, width and number of papillae / surface area $\left(\mathrm{cm}^{2}\right)$.

Table 1 The feed ingredients and calculated chemical analysis of the ration for adult goats

\begin{tabular}{lcll}
\hline Feed ingredients & $\%$ & $\begin{array}{l}\text { Chemical analysis (\%) of the } \\
\text { basal diet on dry matter basis }\end{array}$ & $\%$ \\
\hline Yellow corn . & $55 \%$ & Dry matter (DM) & 82.3 \\
Wheat bran. & $15.8 \%$ & Crude protein (CP) & 14.05 \\
Soybean meal (46\% pt.) & $13.6 \%$ & Ether extract (EE) & 4.63 \\
Soybean meal hulls & $9.5 \%$ & Crude fiber (CF) & 7.31 \\
Molasse & $1.5 \%$ & Ash & 7.01 \\
Vit.\& Min. premixture & $0.3 \%$ & NFE & 49.29 \\
Limestone & $2.4 \%$ & TDN & 70.25 \\
Sodium bicarbonate & $0.4 \%$ & & \\
Sodium chloride & $1 \%$ & & \\
Ammonium chloride & $0.5 \%$ & & \\
Sum & 100 & & \\
\hline
\end{tabular}

2.2. Determination of fermentation parameters:

2.2.1. Ruminal juice collection:

Rumen liquor samples were collected after morning meal, using a suitable stomach tube connected with a suction plastic syringe $250 \mathrm{ml}$ capacity (Grummer et al., 1993). About 100-200 $\mathrm{ml}$ of rumen fluid was collected in sterile, clean and dry beakers. 3-4 hours after feeding (Dolezal et al., 2005).

\subsubsection{Determination of ruminal $\mathrm{pH}$ :}

The rumen fluid was immediately examined for physical properties of ruminal juice $\mathrm{pH}$ using digital electric $\mathrm{pH}$ meter according to Smith (1996).

\subsubsection{Determination of ruminal ammonia nitrogen} concentration:

The ruminal ammonia nitrogen concentrations were determined according to method described by Conway (1957).

2.2.4. Determination of total volatile fatty acids concentration (TVFA):

For later analysis of VFA concentrations, $10 \mathrm{ml}$ sample of rumen fluid was mixed with $2 \mathrm{ml}$ of $25 \%$ (wt./vol) meta- phosphoric acid then frozen at $-20^{\circ} \mathrm{C}$ till analysis of VFA concentrations by steam distillation method according to Warner (1964)

\section{2. 5. Determination of total ruminal protozoal count} $(T P C)$

Total protozoal count was determined according to Javaid et al. (2008). In this method, the usual slide and cover were used for direct microscopic count of protozoa by counting $0.1 \mathrm{ml}$ of diluted ruminal sample. One $\mathrm{ml}$ of strained ruminal juice was separately taken and diluted nine times by addition of $9 \mathrm{ml}$ of Lugol' s iodine solution then counts were made from thirty microscopic fields and calculations were made according to following equation.

Protozoa $/ \mathrm{ml}$ of rumen liquor $=\mathrm{N} \times \mathrm{DF} \times \mathrm{MF} \times 10$; Where:

$\mathrm{N}$ is the average number of protozoa counted per field $\mathrm{DF}$ is the dilution factor (X 9)

MF is the microscopic factor area $\left(1200 \mathrm{~mm}^{2}\right)$

$\mathrm{X} 10$ to obtain number of protozoa in $\mathrm{ml}$ of ruminal fluid Each of the two diluted duplicates was counted and the average was calculated.

2. 3. Determination of quantitative morphometric analysis of ruminal papillae length, width and number of papillae/surface area $\left(\mathrm{cm}^{2}\right)$

After the end of the experiment, immediately after slaughtering (in the evisceration stage), the fore stomachs were carefully removed from the abdominal cavity and samples of rumens (Saccus ventralis) were taken by cutting one piece in a size of $3 \mathrm{~cm}^{2}$ (from their lower portion) from each goat for histological examination (Zitnan et al., 2003). The length, width and number of papillae per / surface area were determined by the computer operated Image $\mathrm{C}$ picture analysis system (Image $\mathbf{J}$ analysis software National Institutes of Health, MD, USA and the program was free on web under https://imagej.nih.gov/ij/download.html) according to Hofmann and Schnorr (1982).

2.6. Statistical analysis:

All collected numerical data were tested statistically by using One-Way ANOVA at 5\% level of significance followed by Duncan multiple tests according to Duncan (1959) were applied to evaluate the differences among means. The statistically homogenous means were denoted by similar alphabets. All analyses were performed using SPSS 16.0 version for Windows.

\section{RESULTS}

3.1. Fermentation parameters:

Data presented in table 2 revealed that, the $\mathrm{pH}$ values were non significantly increased in both Saccharomyces and chitosan groups compared with the control group during all periods of experiment. Also, there were non-significant differences between Saccharomyces and chitosan groups during any period of experiment.

As observed in table 3, there were significant increases in ruminal ammonia nitrogen concentrations in chitosan group when compared with the control group during all periods of experiment except at the $16^{\text {th }}$ week during which a nonsignificant increase was recorded. Also, there were significant decreases in Saccharomyces group when compared with the control group during all periods of treatment except at beginning of collection $\left(8^{\text {th }}\right.$ week $)$ during 
which ruminal ammonia nitrogen concentrations were nonsignificantly decreased in Saccharomyces group when compared with the control group. Moreover, it was found that the ruminal ammonia nitrogen concentrations of chitosan group were significantly higher than that of Saccharomyces group during all experimental periods. With respect to the total VFA, table 4 illustrated that, there was significant increase in total volatile fatty acids produced from fermentation in S. cerevisiae group and non-significant increase in chitosan group when compared with the control group during all periods of treatment. Also, the total volatile fatty acids of $S$. cerevisiae group were significantly higher than that of chitosan group during all periods of treatment except at the $12^{\text {th }}$ and $14^{\text {th }}$ weeks as the total volatile fatty acids of $S$. cerevisiae group were non significantly higher than that of chitosan group.

Table 2 Effect of diet containing Saccharomyces and chitosan on ruminal $\mathrm{pH}($ mean $\pm \mathrm{SE}, \mathrm{n}=12$ )

\begin{tabular}{llll}
\multicolumn{2}{l}{$\mathrm{pH}($ mean $\pm \mathrm{SE}, \mathrm{n}=12)$} & Saccharomyces & Chitosan \\
\hline $8^{\text {th }}$ week & $5.62 \pm 0.12^{\mathrm{a}}$ & $5.77 \pm 0.11^{\mathrm{a}}$ & $6.55 \pm 0.45^{\mathrm{a}}$ \\
$10^{\text {th }}$ week & $5.95 \pm 0.10^{\mathrm{a}}$ & $6.22 \pm 0.14^{\mathrm{a}}$ & $6.00 \pm 0.05^{\mathrm{a}}$ \\
$12^{\text {th }}$ week & $5.87 \pm 0.05^{\mathrm{a}}$ & $6.00 \pm 0.12^{\mathrm{a}}$ & $6.20 \pm 0.17^{\mathrm{a}}$ \\
$14^{\text {th }}$ week & $5.77 \pm 0.07^{\mathrm{a}}$ & $5.90 \pm 0.10^{\mathrm{a}}$ & $6.02 \pm 0.10^{\mathrm{a}}$ \\
$16^{\text {th }}$ week & $5.92 \pm 0.07^{\mathrm{a}}$ & $6.00 \pm 0.03^{\mathrm{a}}$ & $6.42 \pm 0.07^{\mathrm{a}}$ \\
\hline Means with different letters in the same rows are significantly different $(\mathrm{p}<0.05)$.
\end{tabular}

Table 3 Effect of diet containing Saccharomyces and chitosan on ruminal Periods Control Saccharomyces $\quad$ Chitosan

$\begin{array}{llll}8^{\text {th }} \text { week } & 8.28 \pm 0.60^{\mathrm{b}} & 7.78 \pm 0.25^{\mathrm{b}} & 10.11 \pm 0.40^{\mathrm{a}}\end{array}$

$\begin{array}{llll}10^{\text {th }} \text { week } & 8.44 \pm 0.38^{\mathrm{b}} & 5.86 \pm 0.38^{\mathrm{c}} & 10.23 \pm 0.10^{\mathrm{a}}\end{array}$

$\begin{array}{llll}12^{\text {th }} \text { week } & 7.89 \pm 0.42^{\mathrm{b}} & 7.03 \pm 0.40^{\mathrm{c}} & 8.48 \pm 0.29^{\mathrm{a}}\end{array}$

$\begin{array}{llll}14^{\text {th }} \text { week } & 6.69 \pm 0.14^{\mathrm{b}} & 6.16 \pm 0.35^{\mathrm{c}} & 9.57 \pm 0.11^{\mathrm{a}}\end{array}$

$16^{\text {th }}$ week $\quad 7.62 \pm 0.30^{\mathrm{a}} \quad 5.99 \pm 0.22^{\mathrm{b}} \quad 7.68 \pm 0.14^{\mathrm{a}}$

Means with different letters in the same rows are significantly different $(\mathrm{p}<0.05)$

Table 4 Effect of diet containing Saccharomyces and chitosan on rumina

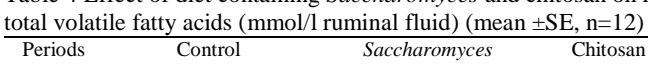

\begin{tabular}{llll}
\hline $8^{\text {th }}$ week & $91.25 \pm 4.78^{\mathrm{b}}$ & $116.50 \pm 2.98^{\mathrm{a}}$ & $102.00 \pm 2.00^{\mathrm{b}}$ \\
$10^{\text {th }}$ week & $106.50 \pm 4.57^{\mathrm{b}}$ & $123.50 \pm 2.95^{\mathrm{a}}$ & $106.75 \pm 6.34^{\mathrm{b}}$ \\
$12^{\text {th }}$ week & $104.00 \pm 2.91^{\mathrm{b}}$ & $122.00 \pm 3.162^{\mathrm{a}}$ & $112.25 \pm 4.9^{\mathrm{ab}}$ \\
$14^{\text {th }}$ week & $99.25 \pm 4.98^{\mathrm{b}}$ & $130.00 \pm 7.11^{\mathrm{a}}$ & $113.00 \pm 6.60^{\mathrm{ab}}$ \\
$16^{\text {th }}$ week & $92.50 \pm 6.75^{\mathrm{b}}$ & $128.50 \pm 7.67^{\mathrm{a}}$ & $94.50 \pm 3.09^{\mathrm{b}}$ \\
\hline
\end{tabular}

Means with different letters in the same row are significantly different $(\mathrm{p}<0.05)$.

As observed in table 5, the total ruminal protozoal count (TPC) was non-significantly increased at the $8^{\text {th }}$ week and $10^{\text {th }}$ week and significantly increased at $12,14,16^{\text {th }}$ weeks in $S$. cerevisiae group when compared with the control group. On the other hand, there was non- significant decrease in the total ruminal protozoal count in chitosan group at beginning of collection at $8^{\text {th }}$ week and $10^{\text {th }}$ week then the total ruminal protozoal count was non-significantly increased in chitosan group when compared with the control group till the end of the experiment. Also, the total ruminal protozoal counts of $S$. cerevisiae was higher than that of chitosan group during all periods of treatment but the difference were significant only during the $10^{\text {th }}, 12^{\text {th }}$ and $16^{\text {th }}$ weeks of the experiment.

3.2. Quantitative morphometric analysis of ruminal papillae length, width and number of papillae/surface area $\left(\mathrm{cm}^{2}\right)$. Table 6 and figures 1-3 showed that length and width of ruminal papillae were significantly increased in S. cerevisiae group and non-significantly increased in chitosan group when compared with the control group. Moreover, the length and width of ruminal papillae were significantly higher in $S$. cerevisiae group than chitosan group. Regarding too a number of ruminal papillae, treatment with $S$. cerevisiae and chitosan caused significant increase in number of ruminal papillae when compared with the control group. On the other hand, there was no significant difference recorded between $S$. cerevisiae group and chitosan group in the number of papillae.

Table 5 Effect of diet containing Saccharomyces and chitosan on total ruminal protozoal count (TPC) and motility (activity) ( x 10 $10^{4} \mathrm{ml} \mathrm{ruminal}$ fluid) (mean $\pm \mathrm{SE}, \mathrm{n}=12$ )

\begin{tabular}{|c|c|c|c|c|c|c|}
\hline \multirow[b]{2}{*}{$\begin{array}{l}\text { Period } \\
\text { s } \\
\text { (weeks }\end{array}$} & \multicolumn{2}{|c|}{$=====$ Control $=====$} & \multicolumn{2}{|c|}{$===$ Saccharomyces $==$} & \multicolumn{2}{|c|}{$======$ Chitosan } \\
\hline & (TPC) & $\begin{array}{l}\text { Protozoa } \\
1 \text { activity }\end{array}$ & (TPC) & $\begin{array}{l}\text { Protozoa } \\
1 \text { activity }\end{array}$ & (TPC) & $\begin{array}{l}\text { Protozoa } \\
1 \text { activity }\end{array}$ \\
\hline $8^{\text {th }} \mathrm{W}$ & $33.03 \pm 1.98^{\mathrm{a}}$ & + & $\begin{array}{l}36.17 \pm 1.7 \\
7^{\mathrm{a}}\end{array}$ & ++ & $29.10 \pm 4.20^{4}$ & ++ \\
\hline $10^{\mathrm{th}} \mathrm{W}$ & $35.77 \pm 3.38^{a}$ & + & $\underset{9^{\mathrm{a}}}{40.55 \pm 5.5}$ & ++ & $25.70 \pm 1.22$ & + \\
\hline $12^{\mathrm{th}} \mathrm{W}$ & $26.17 \pm 1.87$ & + & $\begin{array}{c}53.08 \pm 7.7 \\
6^{\mathrm{a}}\end{array}$ & +++ & $\underset{\mathrm{b}}{30.03 \pm 3.20}$ & ++ \\
\hline $14^{\mathrm{th}} \mathrm{W}$ & $23.71 \pm 2.27$ & + & $\begin{array}{c}38.63 \pm 5.7 \\
2^{ \pm}\end{array}$ & ++ & $30.66 \pm 2.27^{\mathrm{a}}$ & ++ \\
\hline $16^{\mathrm{th}} \mathrm{W}$ & $24.50 \pm 0.86$ & + & $\begin{array}{c}61.00 \pm 4.7 \\
0^{2}\end{array}$ & +++ & $34.00 \pm 2.51$ & ++ \\
\hline
\end{tabular}

Table 6 Effect of diet containing Saccharomyces and chitosan on quantitative morphometrical analysis of ruminal papillae length, width and number of papillae / surface area $\left(\mathrm{cm}^{2}\right)($ mean $\pm \mathrm{SE}, \mathrm{n}=12)$

\begin{tabular}{lccc}
\multicolumn{4}{l}{ number of papillae / surface area $\left(\mathrm{cm}^{2}\right)($ mean \pm SE, $\mathrm{n}=12)$} \\
\hline Morphometric analysis & Control & Saccharomyces & Chitosan \\
\hline Length $(\mathrm{mm})$ & $2.49 \pm 0.14^{\mathrm{b}}$ & $6.26 \pm 0.32^{\mathrm{a}}$ & $3.37 \pm .35^{\mathrm{b}}$ \\
Width $(\mathrm{mm})$ & $0.59 \pm 0.06^{\mathrm{b}}$ & $1.43 \pm 0.04^{\mathrm{a}}$ & $0.63 \pm 0.03^{\mathrm{b}}$ \\
Number $\left(\mathrm{n} / \mathrm{cm}^{2}\right)$ & $50.50 \pm 1.4^{\mathrm{b}}$ & $62.50 \pm 3.77^{\mathrm{a}}$ & $64.75 \pm 1.88^{\mathrm{a}}$ \\
\hline
\end{tabular}

Means with different letters in the same row are significantly different $(\mathrm{p}<0.05)$.

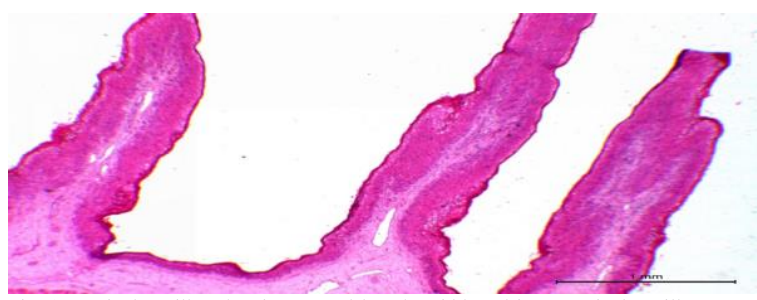
Fig. 1 Ruminal papillae showing normal length, width and inter-ruminal papillae space, $\mathrm{H} \& \mathrm{E}, \mathrm{bar}=1 \mathrm{~mm}$

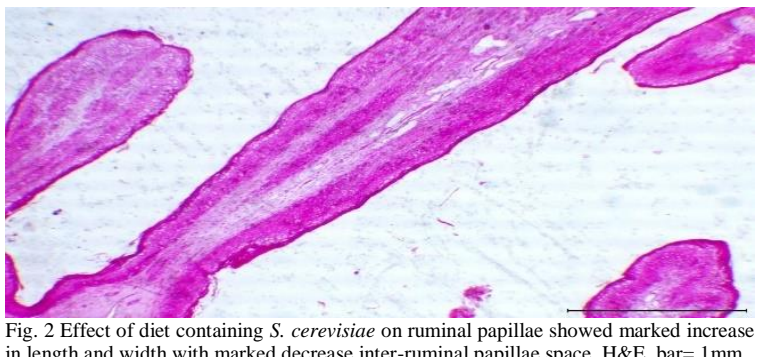

in length and width with marked decrease inter-ruminal papillae space, $\mathrm{H} \& \mathrm{E}, \mathrm{bar}=1 \mathrm{~mm}$

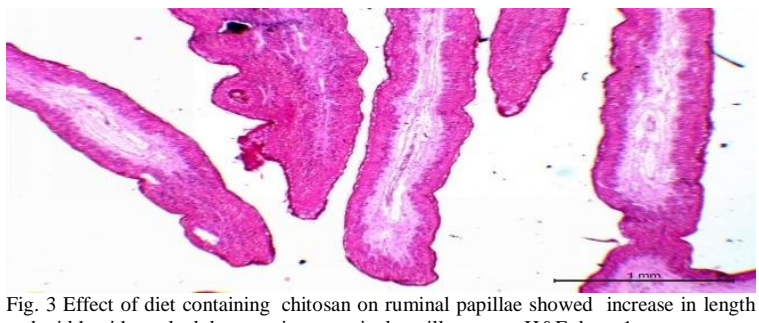

and width with marked decrease inter-ruminal papillae space, $\mathrm{H} \& \mathrm{E}$, bar= $1 \mathrm{~mm}$ 


\section{DISCUSSION}

Concerning the fermentation parameters, the obtained results showed significant decrease in ruminal ammonia nitrogen concentrations of $S$. cerevisiae feeding group than the control. These results agree with results of Dolezal et al. (2005) in cows, Moallem et al. (2009) in dairy cows, Mousa et al. (2012) in ewes, Shaker et al. (2013) in lambs and Bhanderi et al. (2016) in cows. On the other hand, the results of this study are not in agreement with those obtained by Ding et al. (2008) and Reséndiz-Hernández et al. (2012) in lambs, who showed that the ruminal ammonia nitrogen concentrations were non-significantly lower in $S$. cerevisiae group than the control group. Also, Giger-Reverdin et al. (2004) in goats in mid-lactation and Acharya et al. (2017) in Holstein dairy cows obtained that rumen ammonia nitrogen concentrations were non-significant increase compared with control group. In the same respect, Galip (2006) in rams found significant increase in ruminal ammonia nitrogen concentrations in all a yeast culture containing $S$. cerevisiae groups compared with control group. Also, these results are not in agreement with the results of Oeztuerk (2009), who revealed that significant increase in ammonia nitrogen concentration of live yeast culture $S$. cerevisiae vessel than control vessel in in-vitro ruminal fermentation in Rustic of sheep. These results may be attributed to different animal species of the studies or the differences in the level of addition of $S$. cerevisiae used or different strains of $S$. cerevisiae used (Newbold, et. al., 1995) or type of diet (Mir and Mir, 1994) as variation may be due to the level of yeast culture supplementation being $0.5 \mathrm{~g}$ yeast culture animal/day (Ding et al., 2008) and $1.5 \mathrm{~g} /$ day/vessel (Oeztuerk, 2009) invitro ruminal fermentation in Rustic of sheep) or may be due to the variation in animal species (Dolezal et al., 2005; Galip, 2006; Ding et al., 2008; Acharya et al., 2017) in cows, rams, cows, lambs respectively or may be due to the variation different strains of $S$. cerevisiae used $S$. cerevisiae CBS 493.94 (Giger-Reverdin et al., 2004).

The decrease in ruminal ammonia nitrogen concentration may be resulted from increased incorporation of ammonia into microbial protein via improving nitrogen utilization which suggesting improved protein efficiency due to stimulation of microbial activity (Chaucheyras and Fonty, 2001; Lascano and Heinrichs, 2009) and numerous bacterial species, particularly cellulolytic bacteria, use ammonia as a preferential source of nitrogen (Chaucheyras and Fonty, 2002) by soluble growth factors such as organic acids, B vitamins and amino acids, that it was believed to be supplied by $S$. cerevisiae (Waldrip and Martin, 1993) that explain greater number of total bacteria and cellulolytic bacteria (Erasmus et al., 1992).

In the present study, chitosan goat group showed significantly higher ruminal ammonia nitrogen concentration than the control goat group. These results are in accordance with those given by Araújo et al. (2015) in steers and Belanche et al. (2016) in in-vitro ruminal fermentation of cow that showed significant increase in ruminal ammonia nitrogen concentration in chitosan $(\mathrm{CHI})$ containing group compared with the control group. On the contrary, Goiri et al. (2010) in sheep and Del Vallea et al. (2017) in Holstein dairy cows who noted significant decrease in ruminal ammonia nitrogen concentration in chitosan $(\mathrm{CHI})$ containing group compared with the control groups. Also, Goiri et al. (2009 a, b, c) in-vitro rumen digestion and fermentation, Vendramini et al. (2016) in mid- to late-lactating Holstein cows and Dias et al. (2017) in beef steers found that non-significant changes in ruminal ammonia nitrogen concentration in chitosan (CHI) containing group compared with the control group. These results may be attributed to the different animal species of the studies.

The increase in the ruminal ammonia nitrogen concentration levels in chitosan goat group than control goat group may be attributed to chitosan increased crude protein total-tract digestibility (Goiri et al., 2010) and decreased microbial protein synthesis, and this fact can be associated with its antimicrobial activity. Chitosan exerts greater bactericidal effects against gram-positive than gram-negative bacteria, and antimicrobial activity is enhanced at low $\mathrm{pH}$ values (Senel and McClure, 2004). The positive charges of chitosan influence the negative charges of the bacterial cell surface, due to competition with $\mathrm{Ca}^{++}$for electronegative sites on the membrane without conferring dimensional stability, rendering the membrane leaky (Begin and Calsteren, 1999). Also raised concentrations of ammonia observed in our experiment were likely due to an extra supply of ammonia from $\mathrm{CHI}$ and low ammonia uptake by the microbes rather than to increased feed proteolysis (Belanche et al., 2016).

Regarding to total volatile fatty acids, the obtained results revealed significant $(\mathrm{p}<0.05)$ increased in total volatile fatty acids of $S$. cerevisiae feeding group than control. Similar results obtained by Dolezal et al. (2005) in cows, Galip (2006) in rams, Moallem et al. (2009) in cows, Oeztuerk (2009) in vitro ruminal fermentation of sheep, Mousa et al. (2012) in ewes, Shaker et al. (2013) in lambs and Bhanderi et al. (2016) in cows.

On the other hand, Ding et al. (2008) in lambs and ReséndizHernández et al. (2012) in lambs showed non-significantly lower in ruminal TVFA in yeast containing $S$. cerevisiae groups compared with control groups. On the same respect, Giger-Reverdin et al. (2004) in goats found non-significant decrease in ruminal TVFA in yeast containing $S$. cerevisiae group compared with control group. Moreover, GarcõÂa et al. (2000) in sheep showed non-significant increase in total volatile fatty acids in a yeast culture containing $S$. cerevisiae group compared with control group. These results may be attributed to different animal species of the studies or the differences in the level of addition of SC used or different strains of S. cerevisiae used (Newbold, et. al., 1995) or type of diet (Mir and Mir, 1994) as variation may due to the level of yeast culture supplementation being $0.15 \%$ feed of dry base (Reséndiz-Hernández et al., 2012) or may be due to the variation in animal species (Ding et al., (2008) for lambs or may be due to the variation different strains of SC used $S$. cerevisiae (Levucell) (Garcõ̂Aa et al., 2000).

The marked increase in total volatile fatty acids in $S$. cerevisiae group may be attributed to the enhancement of microbial activities (Erasmus et. al., 1992); Ruminal microbial growth was stimulated through making use of specific soluble growth factors such as organic acids, B vitamins and AA provided by added yeast (Nisbet and Martin, 1991).

Chitosan goats group showed non-significant higher total volatile fatty acids concentrations than control goat s' group. These results are in accordance with those given by Goiri et al. (2009c) in in-vitro ruminal fermentation of sheep, Goiri et al. (2010) in sheep, Wencelova et al. (2014) in in-vitro ruminal fermentation of sheep, Araújo et al. (2015) in steers, Belanche et al. (2016) in in-vitro ruminal fermentation of 
Holstein-Frisian cows, Vendramini et al. (2016) in mid- to late-lactating Holstein cows, Zhengxin et al. (2016) in in invitro ruminal fermentation, Dias et al. (2017) in beef steers and Del Vallea et al. (2017) in Holstein dairy cows who revealed that there was no significant variation in total volatile fatty acids concentrations between chitosan goats group and control goats group.

Regarding to total ruminal protozoal count (TPC), there was significantly increase in the protozoal count $(\mathrm{P}<0.05)$ in $S$. cerevisiae groups compared with the control group.

These results agree with the results of Dolezal et al. (2005) in Holstein cow breed and Kumar et al. (2013) in buffalo bulls who found that supplementation of the diet with yeast culture significantly increased the mean protozoal count when compared with the control groups.

On the other hand, Galip (2006) in rams and Vyas et al. (2014) in beef heifers showed that there was no significant difference between Saccharomyces cerevisiae groups and the control groups. These results may be attributed to the variation in animal species. On the same respect, GarcôÂa et al. (2000) in sheep found significant decrease in total ruminal protozoal count in a yeast culture containing $S$. cerevisiae group comparing with the control group. These results may be attributed to different animal species of the studies or the differences in the level of addition of $S$. cerevisiae used or different strains of $S$. cerevisiae used (Newbold, et. al., 1995) or type of diet (Mir and Mir, 1994) as variation may due to the level of yeast culture supplementation being $0.15 \%$ feed of dry base (ReséndizHernández et al. (2012) or may be due to the variation in animal species (Galip, 2006; Vyas et al., 2014) for rams and beef heifers respectively or may be due to and the level of yeast culture supplementation being $1 \mathrm{~g}$ yeast culture/head/day and variation different strains of $S$. cerevisiae used (Levucell) (Garcõ̂̂Aa et al., 2000).

The increased total ruminal protozoal count (TPC) can be explained by the supplying a yeast culture containing $S$. cerevisiae stimulate the metabolic activity of rumen protozoa and increase microbial protein synthesis (Dolezal et al., 2005) by soluble growth factors such as organic acids, B vitamins and amino acids, that it was believed to be supplied by SC (Waldrip and Martin, 1993) that explain greater number of rumen protozoa.

The present study revealed that feeding of chitosan caused non-significant changes in total ruminal protozoal count (TPC) and motility (activity) comparing with the control group. These results are in accordance with those given by Belanche et al. (2016) in in-vitro ruminal fermentation of Holstein-Frisian cows who reported that there were no significant changes in total ruminal protozoal count (TPC) between chitosan and the control groups. On the contrary, Wencelova et al. (2014) in in-vitro ruminal fermentation of sheep found that the addition of chitosan (CHI) caused significant decrease in total ruminal protozoal count (TPC) when compared with the control vessel. These results may be attributed to the different animal species of the studies.

Regarding quantitative morphometric analysis of ruminal papillae in the present study, feeding of $S$. cerevisiae caused significant increase in measures of ruminal papillae (length, width and number of papillae/surface area) when compared with the control group. These results are partially in agreement with those obtained by Kaldmäe et al. (2008) who found significant increase in rumen papillae width and nonsignificant changes in rumen papillae length and number of papillae / surface area of Holstein calves in all a yeast culture containing S. cerevisiae groups compared with the control group. On the other hand, Bugdayci et al. (2016) in goats found that feeding of $S$. cerevisiae caused non-significant changes in rumen papillae lengths in all a yeast culture containing S. cerevisiae groups compared with the control group. Also, Garcia et al. (2018) in lambs found that feeding of $S$. cerevisiae caused non-significant changes in rumen papillae width in all a yeast culture containing $S$. cerevisiae groups compared with the control group. These results may be attributed to the different type of yeast feeding (strain of S. cerevisiae) or dose of yeast culture.

The increased morphometric analysis of ruminal papillae length, width and number of papillae / surface area than the control group can be attributed to that $S$. cerevisiae increase intensity of rumen fermentation from this study that is associated with high concentration of short chain fatty acids and consequently, this will lead to increase the transport of SCFA across the ruminal wall (Gäbel et al., 1991a,b) which stimulating some aspects of rumen morphologic and metabolic development leading to stronger development of rumen papillae (Zitnan et al., 1998) because SCFA affect enlargement of the papillae firstly and increasing the mitotic division of stem cells of the ruminal mucosa so increase number of papillae (Mentschel et al., 2001).

The non-significant changes in morphometric analysis of ruminal papillae length and width in chitosan group may be attributed to the results of total volatile fatty acids concentrations obtained in the present study which revealed non-significant changes in total volatile fatty acids concentrations in chitosan treated group comparing with the control group.

\section{REFERENCES}

1. Acharya, S.; Pretz, J. P.; Yoon, I.; Scott, M. F. and Casper, D. P. (2017): Effects of Saccharomyces cerevisiae fermentation products on the lactational performance of mid-lactation dairy cows. Trans. Anim. Sci. 1: 221-228

2. Araújo, A. P. C.; Venturellia, B. C.; Santosa, M.C.B.; Gardinala R.; Cônsoloa, N. R. B.; Calomenia, G. D.; Freitas, J. E.; R.V.; Gandraa J. R.; Paiva, P. G. and Rennóa, F. P. (2015): Chitosan affects total nutrient digestion and ruminal fermentation in Nellore steers. Anim. Feed Sci. Technol. 206: 114-118

3. Begin, A. and Calsteren, M. R. V. (1999): Antimicrobial films produced from chitosan. Int. J. of Biological Macromolecules. 26: 63-67.

4. Belanche, A.; Pinloche, E.; Preskett, D. and Newbold, C. J. (2016): Effects and mode of action of chitosan and ivy fruit saponins on the microbiome, fermentation and methanogenesis in the rumen simulation technique. FEMS Microbiology Ecology. 92 (1): 1-13

5. Bhanderi, B. M.; Parnerkar, S.; Aggarwal, A.; Shankhpal, S. Thube, H. and Pathan, S. (2016): effect of supplementing of two different commercial strains of yeast cultures on rumen fermentation, Nutrient Digestibility and Biochemical Profile in Kankrej Cows. Int. J. Adv. Res. 4(8): 756-772.

6. Bugdayci, K. E.; Mustafa, N. O.; Oguzf, K.; Albay, M. K. and Oner, J. (2016): Effects of live yeast culture addition into sucrose supplemented diet on fattening performance, some blood and histological parameters in Saanen male kids fed without forage. Ankara Üniv. Vet. Fak. Derg. 63: 163-170.

7. Chaucheyras, F. and Fonty G., (2001): Establishment of cellulolytic bacteria and development of fermentative activities in the rumen of gnotobiotically-reared lambs receiving the microbial additive Saccharomyces cerevisiae CNCM I-1077. Reprod. Nutr. Dev. 41: 57-68. 
8. Chaucheyras, F. and Fonty, G. (2002): Influence of a probiotic yeast (Saccharomyces cerevisiae CNCM I-1077) on microbial colonization and fermentations in the rumen of newborn lambs. Microb. Ecol. Health Dis. 14: 30-36.

9. Chevaux, E. and Fabre, M. M. (2007): Probiotic yeast in small ruminants. Feed Mix, 15 (1) 28029.

10. Conway, E. J. (1957): Micro-diffusion analysis and volumetric error. $4^{\text {th }}$ Edition, Crosby-Lockwood and Son Ltd, London.

11. Del Vallea, T. A.; De Paiva, P. G. ; De Jesusb, E. F. ;De Almeidaa. G. F.; Zanferaria, F.; Costaa, A. G. B. V. B.; Buenoc, I. C. S. and Rennóa, F. P. (2017): Dietary chitosan improves nitrogen use and feed conversion in diets for midlactation dairy cows. Livestock Sci. 201:22-29.

12. Dias, A. O. C.; Goesa, R. H. T. B.; Gandraa, J. R.; Takiyab, C S.; Brancoc, A. F.; Jacaúnaa, A. G.; Oliveiraa, R. T.; Souzaa, C. J. S. and Vazd, M. S. M. (2017): Increasing doses of chitosan to grazing beef steers: Nutrient intake and digestibility, ruminal fermentation, and nitrogen utilization. Anim. Feed Sci. and Technol. 225: 73-80

13. Ding, J.; Zhou, Z. M.; Ren, L. P. and Q. X. Meng (2008): Effect of Monensin and Live Yeast Supplementation on Growth Performance, Nutrient Digestibility, Carcass Characteristics and Ruminal Fermentation Parameters in Lambs Fed Steam-flaked Corn-based Diets. Asian-Aust. J. Anim. Sci. 21 (4): 547 - 554

14. Dolezal, P.; Dolezal, J. and Trinacty, J. (2005): The effect of Saccharomyces cerevisiae on ruminal fermentation in dairy cows. Czech J. Anim. Sci. 50 (11): 503-510.

15. Duguma, G.; Mirkena, T.; Haile, A.; Iñiguez, L. and Okeyo, A. M., (2011): Identification of smallholder farmers and pastoralists' preferences for sheep breeding traits: choice model approach. Animal 5: 1984-1992.

16. Duncan, R. G. (1959): Multiple range and multiple F tests. Biometrics. 11: 1-42.

17. Erasmus, L. J.; Botha, P. M. and Kistner, A. (1992): Effect of yeast culture supplement on production, rumen fermentation and duodenal nitrogen flow in dairy cows. J. Dairy Sci. 75: 3056- 3065.

18. Gabel, G.; Bestmann, M. and Martens, H. (1991a): Influence of diet, short-chain fatty acids, lactate and chloride on bicarbonate movement across the reticulorumen wall of sheep. Zentralbl. Veterinarmed. 38: 523-529.

19. Gabel, G.; Vogler, S. and Martens, H. (1991b): Short-chain fatty acids and $\mathrm{CO} 2$ as regulators of $\mathrm{Na}+$ and $\mathrm{Cl}-$ absorption in isolated sheep rumen mucosa. J. Comp. Physiol. B 161: 419-426.

20. Galip, N. (2006): Effects of dietary Saccharomyces cerevisiae live yeast culture supplementation on ruminal digestion and protozoa count in rams fed with diets with low or high ratio forage/concentrate. Revue. Méd. Vét. 157 (12): 609-613

21. Garcia D. T, Ferriani B. A., Jacovaci, F. A., Cabreira J. C., Bolson D. C. and Pratti D. J. L. (2018): Inclusion of live yeast and mannan- oligosaccharides in high grain-based diets for sheep: Ruminal parameters, inflammatory response and rumen morphology. PLoS ONE 13 (2) 1-12.

22. GarcôÂa, C.C.G.; Mendoza, M.G.D.; GonzaÂlez, M. S.; Cobos, P. M.; Ortega C. M. E. and Ramirez L. R. (2000): Effect of a yeast culture (Saccharomyces cerevisiae) and monensin on ruminal fermentation and digestion in sheep. Anim. Feed Sci. and Technol. 83: 165 \pm 170 .

23. Giger-Reverdin, S.; Sauvant, D.; Tessier, J.; Bertin, G. and Morand Fehr, P. (2004): Effect of live yeast culture supplementation on rumen fermentation in lactating dairy goats. South African J. of Anim. Sci. 34 (1): 59-61.

24. Goiri, I.; Garcia-rodriguez, A. and Oregui, L. M. (2009a): Effects of chitosans on in vitro rumen digestion and fermentation of maize silage. Anim. Feed Sci. Technol. 148: 276-287.

25. Goiri, I.; Garcia-Rodriguez, A. and Oregui, L. M. (2009b): Effect of chitosan on mixed ruminal microorganism fermentation using the rumen stimulation technique (Rustic). Anim. Feed Sci. Technol. 152: 92-102.

26. Goiri, I.; Oregui, L. M. and Garcia-Rodriguez, A. (2009c) Dose-response effects of chitosan on in vitro rumen digestion and fermentation of mixtures differing in forage-toconcentrate ratios. Anim. Feed Sci. Technol. 151: 215-227.

27. Goiri, I.; Oregui, L. M. and Garcia-Rodriguez, A. (2010): Use of chitosan to modulate ruminal fermentation of a 50:50 forage-to-concentrate diet in sheep. J. Anim. Sci. 88: 749-755.

28. Grummer, R. R.; Melissa, L. L. and Barmore, J. A. (1993) Rumen fermentation and lactation performance of cows fed roasted soybeans and tallow, J. Dairy Sci. 76: 2674-2681.

29. Hofmann, R. R. and Schnorr, B. (1982): The functional morphology of proventriculi. Ferdinand Enke. Verlag., Stuttgart, 170.

30. Hong, H. A.; Duc, L. H and Cutting, S. M. (2005): The use of bacterial spore formers as probiotics. FEMS Microbiol. Rev. 29: 813-835.

31. Javaid, A.; Nisa, M.; Sarwar, M. and Aasif Shahzad, M. (2008): Ruminal Characteristics, Blood pH, Blood Urea Nitrogen and Nitrogen Balance in Nili-ravi Buffalo (Bubalus bubalis) Bulls Fed Diets Containing Various Levels of Ruminally Degradable Protein. Asian-Aust. J. Anim. Sci. 21 (1): $51-58$

32. Kaldmäe, H; Suurmets, H.; Järveots, T.; Suuroja, T. and Kärt, O. (2008): effects of supplemental yeast (Saccharomyces cerevisiae) culture on rumen development in calves. Theoretical aspects of farm diversification 19-23.

33. Kumar, D. S.; Prasad, Ch. S. and Prasad, R. M. V. (2013): Effect of yeast culture (Saccharomyces cerevisiae) on ruminal microbial populations IN buffalo BULLS. Buffalo Bulletin $\mathrm{j}$. 32 (2): 116-119.

34. Lascano, G. J. and Heinrichs, A. J. (2009): Rumen fermentation pattern of dairy heifers fed restricted amounts of low, medium, and high concentrate diets without and with yeast culture. Livest. Sci. 124: 48- 57.

35. Li, H. Y.; Yan, S. M.; Shi, B. L. and Guo, X. Y. (2009): Effect of Chitosan on Nitric Oxide Content and Inducible Nitric Oxide Synthase Activity in Serum and Expression of Inducible Nitric Oxide Synthase mRNA in Small Intestine of Broiler Chickens. Asian-Aust. J. Anim. Sci. 22: 1048-1053.

36. Lu, Y. H.; Lueders, T.; Friedrich, M. W. and Conrad, R. (2005): Detecting active methanogenic populations on rice roots using stable isotope probing. Environ. Microbiol. 7: 326-336.

37. Mentschel, J.; Leiser, R.; Mulling, C.; Pfarrer, C. and Claus, R. (2001): Butyric acid stimulates rumen mucosa development in the calf mainly by a reduction of apoptosis. Arch. Tierenahr. 55: 85-102.

38. Mir, Z. and Mir, P. S. (1994): Effect of the addition of live yeast (Saccharomyces cerevisiae) on growth and carcass quality of steers fed high-forage or high-grain diets and on feed digestibility and in into degradability. J. Anim. Sci. 72: 537-545.

39. Moallem, U.; Livshitz, L. and Zachut, M. (2009): Effect of Saccharomyces cerevisiae fermentation product (XP) on energetic efficiency of diet fed to high producing dairy cows during the hot season. J. Anim. Sci Vol. 92, E-Suppl. 2/J. Dairy Sci. Vol. 97 (1): 327-328

40. Mousa, K. h. M.; El-Malky, O. M.; Komonna, O. F. an Rashwan, S. E. (2012): Effect of some yeast and minerals on the productive and reproductive performance in ruminants. J. of American Sci. 8(2): 291-303.

41. Nagaraja, T. G. (2012): A Microbiologist's View on Improving Nutrient Utilization in Ruminants. In: 23rd Kansas State University, College of Vet. Medicine, Manhattan (11):51-54

42. Newbold, C. J.; Wallace R. J.; Chen, X. B. and McIntosh, F. M. (1995): Different strains of Saccharomyces cerevisiae differ in their effects on ruminal bacterial numbers in vitro and in sheep. J. Anim. 73: 1811-1818. 
43. Nisbet, D. J. and Martin, S. A. (1991): Effect of a Saccharomyces cerevisiae culture on lactate utilization by the ruminal bacterium Selenomonas ruminantium. J. Anim. Sci. 69:4628.

44. Oeztuerk, H. (2009): Effects of live and autoclaved yeast cultures on ruminal fermentation in vitro. J. of Anim. and Feed Sci. 18: 142-150

45. Polizel, D. M.; Mezzena, L. G.; Souza, G. R. A. de; Gentil, R. S.; Ferreira, E. M. and Alves, A. P.; Susin, F. I. (2016): Performance and carcass traits of goat kids fed highconcentrate diets containing citrus pulp or soybean hulls. Ciência Rural, Santa Maria. 46 (4): 707-712.

46. Reséndiz-Hernández, M.; Bárcena-Gama, J. R.; CrosbyGalván, M. M.; Cobos-Peralta, M.; Herrera-Haro, J.; Hernández-García, P. A. and Carreón-Luna, L. (2012): Effect of Organic Selenium and Chromium and Saccharomyces cerevisiae. Publicado como ARTÍCULO en Agrociencia. 46 (8): 745-755

47. Senel, S. and McClure, S. J. (2004): Potential applications of chitosan in veterinary medicine. Advanced Drug Delivery Review. 56: 1467-1480.

48. Seo, K. J.; Kim, S. W.; Kim, M. H.; Upadhaya, S. D.; Kam, D. K. and Jong, K. (2010): Direct-fed Microbials for Ruminant Animals. Asian-Aust. J. Anim. Sci. 23 (12): 1657 - 1667.

49. Shaker, A. H. and Ali, A. S. (2013): Effect of Feeding Different Levels of Dietary Protein and Addition of Baker's Yeast (Saccharomyces cerevisiae) on Rumen Fermentation Characteristics of Awassi Male Lambs. KSU J. Nat. Sci. 16 (2) 39-47.

50. Smith, B. P. (1996): Large animal internal medicine. Disease of horses, cattle, sheep and goats. $2^{\text {nd }}$ ed, Mosby, USA. $843-$ 851 .

51. Vendramini, T.H.A.; Takiyaa, C. S.; Silvaa, T. H.; Zanferaria F.; Rentasa, M. F.; Bertonia, J. C.; Consentinia, C. E. C.; Gardinala R.; Acedob, T. S. and Rennóa, F. P. (2016): Effects of a blend of essential oils, chitosan or monensin on nutrient intake and digestibility of lactating dairy cows. Anim. Feed Sci. and Technol. 214: 12-21.

52. Vyas, D.; Uwizeye, A.; Mohammed, R.; Yang, W. Z.; Walker, N. D. and Beauchemin, K. A. (2014): The effects of active dried and killed dried yeast on subacute ruminal acidosis, ruminal fermentation, and nutrient digestibility in beef heifers. J. Anim. Sci., .92:724-732

53. Waldrip, H. M. and Martin S. A., (1993): Effects of an Aspergillus oryzae fermentation extract and other factors on lactate utilization by the ruminal bacterium Megasphaera elsdenii. J. Anim. Sci. 71:2770.

54. Warner, A. C. I. (1964): Production of volatile fatty acid in the rumen. Methods significantly of measurements. Nutr. Abstr. and Rev. 34: 339.

55. Wencelova, M.; Varadyova, Z.; Mihalikova K.; Kisidayova, S. and Jalc, D. (2014): Evaluating the effects of chitosan, plant oils, and different diets on rumen metabolism and protozoan population in sheep. Turk. J. Vet. Anim. Sci. 38: 26-33.

56. Zhengxin, M.; Donghyeon, K.; Adegbola, T. A.; Sanghoon, K. o.; Klibs, G. and Kwangcheol, C. J. (2016): Chitosan Microparticles Exert Broad-Spectrum Antimicrobial Activity against Antibiotic-Resistant Micro-organisms without Increasing Resistance, ACS Appl. Mater. Interfaces., 8, 10700-10709

57. Zitnan, R.; Voigt J.; Schönhusen, U.; Wegner, J.; Kokardova M., Hagemeister, H.; Levkut, M.; Kuhla, S. and Sommer, A. (1998): Influence of dietary concentrate to forage ratio on the development of rumen mucosa in calves. Arch. Anim. Nutr. 51: 279-291.

58. Zitnan, R; Kuhla, S.; Nurnberg, K.; Schonhuse, U.; Ceresnakova, Z., Sommer, A.; Baran, M.; Greserova, G. and Voigt, J. (2003): Influence of the diet on the morphology of ruminal and intestinal mucosa and on intestinal carbohydrase levels in cattle. Vet. Med. Czech 48: 177-182. 